\title{
Rights of the child and adolescent: current challenges
}

\author{
Regina Aparecida Garcia de Lima
}

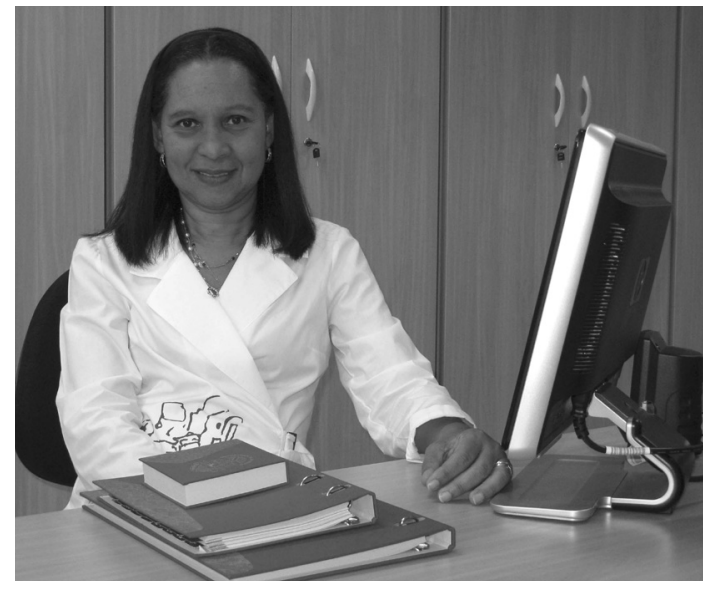

As from the $20^{\text {th }}$ century, in different parts around the world, children's rights have become acknowledged in laws and codes. Childhood-related issues are incorporated on the social policy agenda. Because of their vulnerable condition, in 1923, the first international document in defense of children was issued, incorporated into the "Declaration of the Rights of the Child", known as the Geneva Declaration, in 1924. This document declares that, independently from color, creed and age, children should be guaranteed conditions for normal development, i.e. they should be fed when hungry, taken care of when ill; they should have freedom, be protected from any form of exploration and their talents should be placed at the service of man ${ }^{(1)}$.

In 1948, after the atrocities of the World War Two, the United Nations Assembly issued the "Universal Declaration of Human Rights". Nevertheless, despite the perspective of covering human beings indistinctly, another document was elaborated, specifically to address children's rights. In 1959, the Declaration of the Rights of the Child was unanimously approved in the General Assembly of the United Nations. The most recent documents about the rights of children and adolescents is the 2007 Barcelona Declaration, which presents strategies to defend children and adolescents against poverty, all types of abuse and discrimination, as well as to guarantee adequate health care, education and social participation $^{(1)}$.

In Brazil, the movement to protect children gains visibility through the notoriety resulting from the International Year of the Child, in 1978. Since then, non-governmental institutions have created alliances on behalf of children and adolescents' rights, culminating in a public policy translated in the Statute of the Child and Adolescent-ECA, in 1990(2). The ECA is considered a landmark in the defense of Brazilian children and adolescents' rights; guaranteed rights cover the right to life and health. Due to the specificity of child and adolescent' rights, however, other resolutions were approved, in line with international guidelines, such as the Rights of Hospitalized Children and Adolescents ${ }^{(3)}$, in 1995.

The rights of hospitalized children and adolescents include the protection of life and health, with absolute priority and without any form of discrimination; being hospitalized when necessary for one's treatment, without any distinction in social class, economic condition, race or religious belief; not being or remaining in hospital unnecessarily for any reason except for the best treatment; being accompanied by one's mother, father or responsible caregiver during the hospitalization period, as well as receiving visits; not being separated from one's mother at birth; receiving breastfeeding unrestrictedly; not feeling pain if there are means to avoid it; having adequate knowledge of one's disease, therapeutic 
and diagnostic care, respecting the child's cognitive phase; besides receiving psychological support when necessary; enjoying some form of recreation, health education programs, accompaniment of the school curriculum during hospitalization; parents or responsible caregivers' active participation in treatment and prognosis, receiving information about the procedures the child will be submitted to; receiving spiritual and religious support, in accordance with the family's practice; not being subject to clinical essays, diagnostic and therapeutic tests without the informed consent of the parents or responsible caregivers and their own, if they are able to decide; receiving all therapeutic resources available for cure and rehabilitation; protection against any form of discrimination, neglect or mistreatment; respect for one's physical, psychic and moral integrity; preservation of one's image, identity, autonomy of personal values, spaces and objects; not being used by mass communication means without the parents or responsible caregivers' expressed will or against their own will, safeguarding ethics; confidentiality of one's clinical data, as well as the right to know the data, filed at the institution during legally established terms; having a dignified death, together with one's relatives, when available therapeutic resources are exhausted; having hospitals fully respect one's constitutional rights and rights in the Statute of the Child and Adolescent.

These rights are essential in care delivery to hospitalized children and adolescents, but some of them are hardly respected. Regarding the right not to be objects of clinical essays, diagnostic and therapeutic tests, without the parents or responsible caregivers' informed consent and their own, if they are able to decide (article No. 12), health professionals and researchers can also use National Health Council Resolution 196/96(4) for reference. This important instrument regulates research involving human beings.

As the protection of scientific research participants' rights is guaranteed in the informed consent term, when studies involve children and adolescents, their legal representatives should read and sign the term. The participants' consent should also be obtained though, even if their autonomous decision-making competency is limited. In that case, researchers should obtain the children and adolescents' assent, to be distinguished from the consent, signed by adults ${ }^{(4)}$. These documents are not a mere formality, as they register the voluntary decision to participate in research.

Researchers are responsible for protecting the dignity and autonomy of their study participants. Members of the scientific community should also disseminate these documents, so that more and more children and adolescents can fully enjoy their rights.

\section{References}

1. Sousa C, Araujo C. The ethical rights of children: yesterday and today. Pediatric Nurs. 2011;37(3):141-3.

2. Ministério da Ação Social (BR). Centro Brasileiro para a Infância e Adolescência. Estatuto da Criança e do Adolescente. Brasília; 1990. 61 p.

3. Conselho Nacional dos Direitos da Criança e do Adolescente (BR). Resolução n41 de 13 out 1995. Diário Oficial da União, seção 1, 17 out 1995.

4. Ministério da Saúde (BR). Conselho Nacional de Saúde. Comissão Nacional de Ética em Pesquisa. Manual operacional para comitês de ética em pesquisa. 4 ed. Brasília: Editora do Ministério da Saúde; 2007.

Regina Aparecida Garcia de Lima is Scientific Editor of the Revista Latino-Americana de Enfermagem and Full Professor of the Escola de Enfermagem de Ribeirão Preto, Universidade de São Paulo, WHO Collaborating Centre for Nursing Research Development, Brazil, e-mail: limare@eerp.usp.br. 